\title{
Aging study of a lead-acid storage bank in a multi-source hybrid system
}

\author{
El Mehdi Laadissi ${ }^{1}$, Jaouad Khalfi ${ }^{2}$, Fouad Belhora ${ }^{3}$, Chouaib Ennawaoui ${ }^{4}$, Abdessamad El Ballouti ${ }^{5}$ \\ 1,3,4,5 Laboratory of Engineering Sciences for Energy (LabSIPE), National School of Applied Sciences, \\ Chouaib Doukkali University, Morocco \\ ${ }^{2}$ Department of Physics, Laboratory of Electrical Systems and Telecommunications, Faculty of Sciences and Technology, \\ Cadi Ayyad University, Morocco
}

\begin{tabular}{|c|c|}
\hline Article Info & ABSTRACT \\
\hline Article history: & \multirow{9}{*}{$\begin{array}{l}\text { Autonomous and grid-connected systems play an important role in the } \\
\text { massive integration of renewable energy sources necessary for the global } \\
\text { development of a sustainable society. In this regard, the analysis of the } \\
\text { behavior of electrochemical storage devices such as lead-acid batteries } \\
\text { installed on hybrid energy systems and microgrids in terms of lifespan and } \\
\text { economic profitability is an important research subject. The purpose of this } \\
\text { article is to present a methodology for calculating the aging rate of a storage } \\
\text { battery inserted in a hybrid multisource system. The approach consists in first } \\
\text { knowing the solicitations of the battery during a year knowing at every } \\
\text { moment its state of charge. This curve is obtained from a dynamic simulator } \\
\text { taking into account the intermittences of the sources and the load. The second } \\
\text { step is to determine the number of cycles and the depth of discharge of each } \\
\text { from the stat of charge. Finally, based on the battery life characteristic given } \\
\text { by the manufacturer (cycle number vs. discharge depth), the aging rate of the } \\
\text { battery for one year of operation is determined. }\end{array}$} \\
\hline Received Nov 11, 2019 & \\
\hline Revised Mar 30, 2020 & \\
\hline Accepted Apr 21, 2020 & \\
\hline Keywords: & \\
\hline Battery aging rate & \\
\hline Diesel generator & \\
\hline Hybrid system multi-sources & \\
\hline Renewable energies & \\
\hline
\end{tabular}

Copyright $\odot 2020$ Institute of Advanced Engineering and Science. All rights reserved.

\section{Corresponding Author:}

El Mehdi Laadissi,

Laboratory of Engineering Sciences for Energy (LabSIPE),

National School of Applied Sciences,

Chouaib Doukkali University, El Jadida, Morocco.

Email: Laadissi.e@ucd.ac.ma

\section{INTRODUCTION}

In recent years, hybrid renewable energy sources coupled with a diesel generator and a battery pack [1] have been widely used for the electrification of isolated sites. The advantage of these systems is the combination of renewable energies and fossil fuels on the one hand and the guarantee of autonomy of the systems on the other hand. Several authors have based their work on the use of solar generator, wind generator, gas turbine, diesel generator and storage systems to build autonomous hybrid configurations. In [2-5], the authors have dimensioned hybrid installations with different architectures based on the optimization of a cost function expressed in $€$ or $\$$. In [6-8], the authors have based the optimization of an "objective" function expressed in MJ in order to size a hybrid dynamic system comprising a photovoltaic generator (GPV), a wind generator (GE) and storage system (battery). The "objective" function used in [6-8] takes into account the life cycle of the components but based only on the average life given by the manufacturers. For example, five years for Lead Acid batteries VRLA. To continue this kind of study, it is important to be able to express the life cycle of the batteries in order to take it into account in a global optimization algorithm.

The purpose of this article is to study the aging storage bench used in hybrid multisource systems. To illustrate the approach followed, the multisource system consists of a photovoltaic generator (PV), a wind generator (GE), a diesel generator (GD) and a storage system based on lead-acid batteries. 


\section{RESEARCH METHOD}

The dynamic simulator illustrated in Figure 1, represents a functional implementation of the multi-source hybrid electrification system studied. The energy sources of the simulator come from renewable energies (photovoltaic and wind), and fossil energy (diesel generator) with a storage system.

The inputs of the dynamic simulator are as follows:

a) Vectors defining the metrological data irradiation $I_{r}\left[\mathrm{w} / \mathrm{m}^{2}\right]$, ambient temperature $T_{a}\left[\mathrm{C}^{\circ}\right]$ and wind speed $w_{s}[\mathrm{~m} / \mathrm{s}]$.

b) Solar field surface $A p v$, rotor surface of the wind turbine $A w t$, the battery capacity Ah and the fuel supply of the diesel generator Fuel $[\mathrm{l} / \mathrm{h}]$.

c) Consumption profile $P_{\text {load }}[w]$.

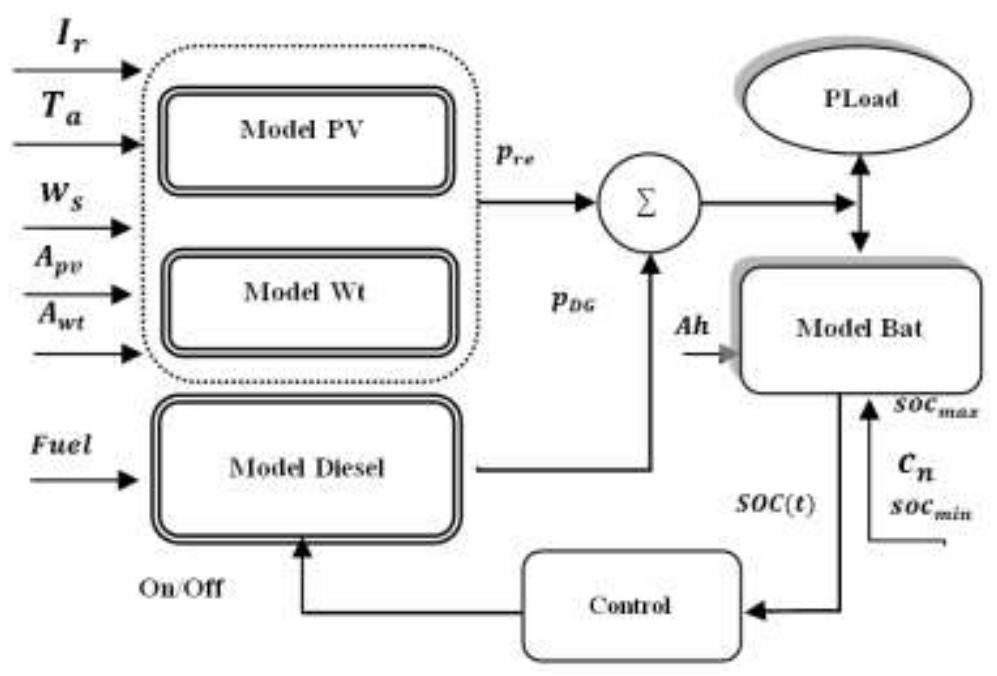

Figure 1. Block diagram of the dynamic simulator

\subsection{Power models of the hybrid system power sources}

The power delivered by the different energy sources depends on several parameters. For the solar generator, the parameters influencing the power supplied by the generator are:

- The metrological data of the site: ambient temperature Ta and irradiation $I_{r}$.

- The surface $A_{p v}$ of the solar panel field.

- For the wind generator, the power supplied is influenced by:

- The metrological data of the site: The ambient temperature Ta and the wind speed $w_{s}$.

- The surface swept by the rotor of the wind turbine $A_{w t}$.

The power delivered by the diesel generator depends on the amount of fuel consumed by the diesel generator during one hour of operation. Four mathematical models are used to model the energy sources of the hybrid system, a model for the solar generator, a model for the wind generator, a model for the diesel generator and a model for the storage battery [9].

\subsubsection{Modeling of the solar generator}

The model of the solar generator presented by [1] is given by the following expression:

$$
\mathrm{P}_{\mathrm{pv}}\left[\mathrm{w} / \mathrm{m}^{2}\right]=\eta_{\mathrm{G}} \times \mathrm{A}_{\mathrm{pv}} \times \mathrm{I}_{\mathrm{r}}
$$

With:

$\eta_{G}$ : The overall efficiency of the generator given by the following equation:

$$
\eta_{G}=\eta_{r} \times \eta_{p v} \times\left[1-\beta_{t} \times\left(T_{c}-T_{N O C T}\right)\right]
$$

With:

$\eta_{r} \quad:$ The reference yield of the solar generator.

$\eta_{p v} \quad:$ The degradation factor of the solar generator according to its lifetime. 
$\beta_{t} \quad:$ The coefficient of the influence of the temperature of the photovoltaic cells on the efficiency of the generator.

The temperature $T_{c}$ in $\left({ }^{\circ} \mathrm{C}\right)$ of the junction or the cell of the photovoltaic panel is given by:

$$
T_{c}=30+0.075 \times\left(300-I_{r}\right)+1.14 \times\left(T_{a}-25\right)
$$

$T_{N O C T}:$ is the nominal operating temperature (Nominal Operating Cell Temperature).

$I_{r} \quad$ : solar Irradiation.

\subsubsection{Modeling of the wind generator}

The power model of the wind generator is given by the following expression $[1,6]$ :

$$
\begin{aligned}
& P_{w g}=\frac{1}{2} C_{p} \times \eta_{g b} \times \eta_{g} \times \rho \times A_{w t} \times w_{s}^{3} \\
& P_{w g}=\frac{1}{2} \eta_{G} \times \rho \times A_{w t} \times w_{s}^{3}
\end{aligned}
$$

With:

$$
\begin{array}{ll}
C_{p} & : \text { Efficiency of the turbine. } \\
\eta_{g b} & : \text { Efficiency of the drive controller. } \\
\eta_{g} & : \text { Efficiency of the generator. } \\
A_{w t}\left[\mathrm{~m}^{2}\right] & : \text { The area swept by the rotor of the turbine. } \\
w_{s}[\mathrm{~m} / \mathrm{s}] & : \text { The wind speed. } \\
\rho\left[\mathrm{kg} / \mathrm{m}^{3}\right] & : \text { the density of the air. } \\
\rho=\left(\frac{353.049}{T_{a}}\right) \times \exp \left(-0.034 \times \frac{Z}{T_{a}}\right)
\end{array}
$$

$Z[m]$ : Altitude and $T_{a}$ the ambient temperature.

\subsubsection{Modeling of the diesel generator}

Variation of the state of charge SOC(t) of the battery as shown in Figure 2. The power model of the diesel generator according to the fuel is presented by the following expression [1]:

$$
P_{G D}=0.04155 \times Q_{\text {fuel }}^{2}+4.2 \times Q_{\text {fuel }}
$$

With:

$[\mathrm{kW}] \quad$ : The power supplied by the diesel generator.

$Q[\mathrm{~L}] \quad$ : The amount of fuel consumed for one hour.

\subsubsection{Modeling of the storage system (lead acid battery)}

The charge-discharge model of the lead-acid battery is given by the following expression:

$$
\operatorname{SOC}(t)=\operatorname{SOC}(t-1)+\left(P_{G}(t)-\frac{P_{\text {load }}(t)}{\eta_{D C-A C} \times \eta_{w r}}\right) \times \frac{\eta_{\text {Bat }}}{V_{\text {bus }}} \times \Delta t
$$

With:

$$
\begin{aligned}
& P_{G}(t)=P_{r e}(t)+P_{G D}(t) \\
& \mathrm{P}_{\mathrm{G}}(\mathrm{t})=\mathrm{P}_{\mathrm{pv}}(\mathrm{t}) \times \eta_{\mathrm{DC}-\mathrm{DC}}+\mathrm{P}_{\mathrm{wt}}(\mathrm{t}) \times \eta_{\mathrm{AC}-\mathrm{DC}}+\mathrm{P}_{\mathrm{DC}} \times \eta_{\mathrm{AC}-\mathrm{DC}}
\end{aligned}
$$

With:

$P_{r e} \quad$ : Power of renewable generators.

$P_{G D} \quad$ : Power of the diesel generator.

$P_{\text {load }}(t)$ : Power demanded by the load for a moment of time $t$.

$\eta_{\text {Bat }}$ : Battery charge-discharge efficiency, equal to 1 during charging and equal to 0.8 during discharge $[1,3]$. 
SOC : The state of charge of the battery (State of Charge).

$\Delta t \quad$ : Simulation step.

The nominal capacity of the storage bank according to the unit capacity of a battery is expressed by (11) [1].

$$
C_{n}=\left(\frac{N_{\text {Bat }}}{N_{\text {Bats }}}\right) \times C_{\text {Bat }}=N_{\text {Batp }} \times C_{\text {Bat }}
$$

With:

$$
\begin{aligned}
& N_{\text {Bat }}: \text { The total number of batteries. } \\
& N_{\text {Bats }}: \text { The number of batteries connected in series. } \\
& N_{\text {Batp }}: \text { The number of batteries connected in parallel. }
\end{aligned}
$$

$C_{\text {Bat }}[\mathrm{Ah}]:$ Battery capacity.

The relationship between the maximum state of charge and the minimum state of charge is given by the following formula (12):

$$
S O C_{\min }=(1-D O D) \times S O C_{\max }
$$

With:

DOD : Represents the depth of discharge.

In our study the maximum depth of discharge $D O D_{\operatorname{Max}}$ is chosen equal to $65 \%$.

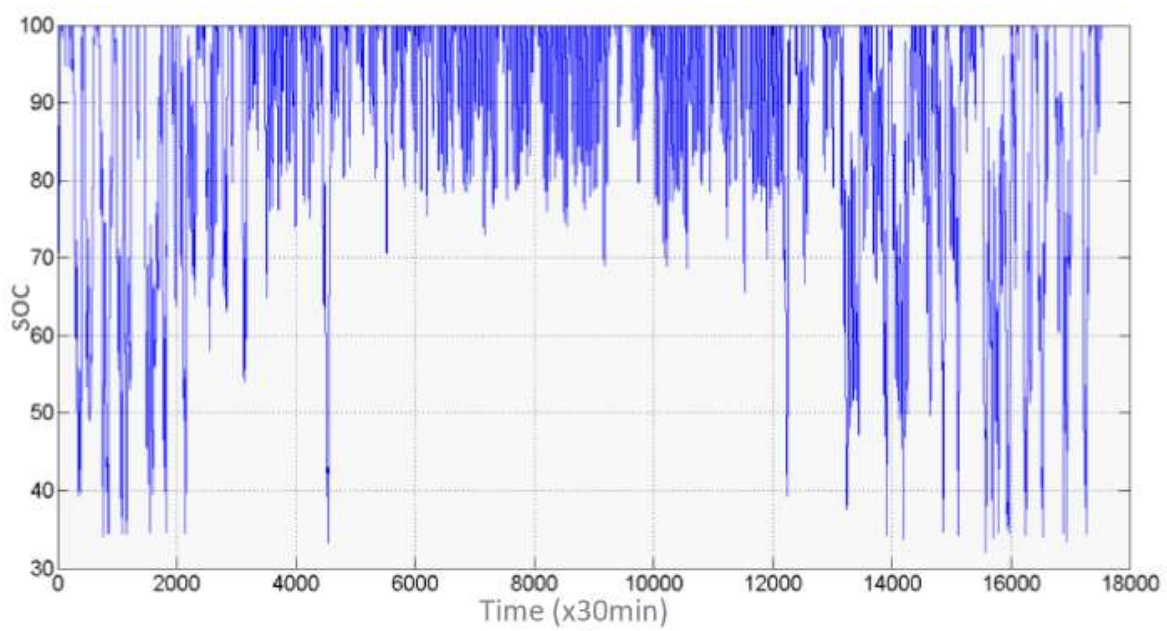

Figure 2. Variation of the state of charge $\operatorname{SOC}(\mathrm{t})$ of the battery

\subsection{Operation of the hybrid system}

According to Figure 1, the permanent satisfaction of the load is ensured by the two renewable generators, the diesel generator (GD) and the storage battery. The operation of the diesel GD depends exclusively on the state of charge/ discharge of the battery. Thus, in order to control the independent operation (on/off) of the GD two thresholds $\left(S O C_{d \max }\right.$ et $\left.S O C_{d \min }\right)$ are defined. The dynamic simulator runs on one-year data with a 30-minute sampling rate. This one allows to know all the powers provided by the generators, the losses of energy and the state of charge of the battery (SOC) with each sampling step during a year.

The dynamic simulator is tested for different operating conditions. These conditions are defined by the operating depths of the power storage bank. During the first simulation test, the data used are shown in Table 1. Figure 2 represents the SOC curve obtained over one year of dynamic simulation with meteorological data from a Moroccan site. From Figure 3, it can be seen that the number of start/stop of the diesel generator depends on the state of charge of the battery. 


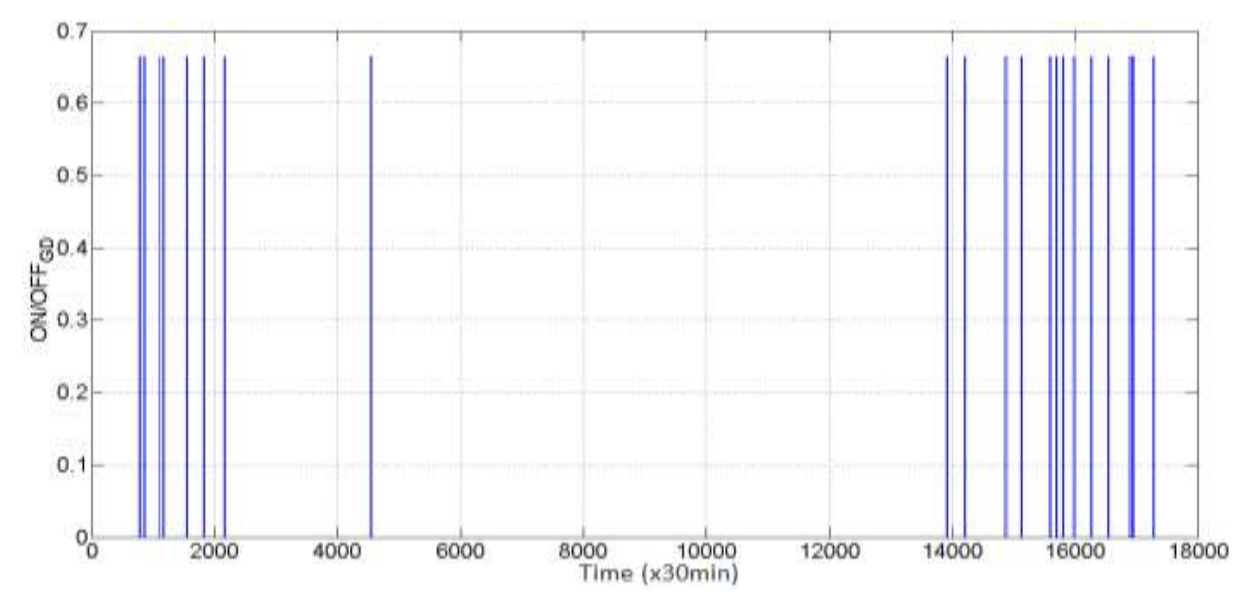

Figure 3. On and off state of the diesel generator

Table 1. Input data for the dynamic simulator

\begin{tabular}{cccccccc}
\hline Parameters & $\boldsymbol{A}_{\boldsymbol{p v}}\left[\boldsymbol{m}^{2}\right]$ & $\boldsymbol{A}_{\boldsymbol{w} t}\left[\mathbf{m}^{2}\right]$ & $\mathbf{A h}[\mathbf{A h}]$ & $\boldsymbol{D O D}_{\max }$ & $\mathbf{S O C}_{\text {dmax }}$ & $\mathbf{S O C}_{\mathrm{dmin}}$ & $\begin{array}{c}\mathbf{P}_{\text {load }} \\
{[\mathbf{K w h} / \mathrm{ye}]}\end{array}$ \\
\hline values & 13 & 2.2 & 220 & $65 \%$ & $70 \%$ & $35 \%$ & 2193 \\
\hline
\end{tabular}

\section{a) Modelling the life cycle of the battery}

The study is based on the manufacturer's data that characterizes the life of the battery by the number of cycles depending on the depth of discharge of each. The types of lead-acid batteries most commonly used for hybrid electrification systems are open conventional stationary batteries and VRLA (Valve Regulated Lead Acid) sealed batteries [10-16]. In each class, two different internal architectures are used: flat plate technology and tube plate technology. In this study, we will present the variations in the number of cycles $N_{c}$ as a function of the DOD discharge depths for these two types of batteries. For this purpose, in order to trace the characteristic curves of the studied batteries, we are based on manufacturer data. Table 2 shows the points given by the manufacturer for each type of battery.

Table 2. Number of battery cycles depending on the discharge depth DOD

\begin{tabular}{cccccccc}
\hline $\mathrm{N}_{\mathrm{c}} /$ DOD & $20 \%$ & $30 \%$ & $40 \%$ & $60 \%$ & $80 \%$ & $90 \%$ & $100 \%$ \\
\hline BGEL1 & 4250 & 2750 & 2125 & 1375 & 1000 & 970 & 800 \\
BGEL2 & 6250 & 4200 & 3200 & 2080 & 1500 & 1300 & 1250 \\
BGEL3 & 6450 & 5800 & 3050 & 2800 & 2560 & 1800 & 1650 \\
BS1 & 4500 & 3000 & 2250 & 1500 & 1250 & 1000 & 900 \\
BS2 & 8400 & 5500 & 4250 & 2800 & 2100 & 1800 & 1700 \\
BS3 & 6000 & 4000 & 3000 & 2000 & 1500 & 1300 & 1200 \\
\hline
\end{tabular}

With:

BGEL1: Flat plate battery type GEL VRLA SOLAR.

BGEL2: VELA SOLAR Block Flat Plate Battery.

BGEL3: GEL VRLA A600 SOLAR tubular plate battery.

BS1: Stationary flat plate battery type $\mathrm{OPzS}$.

BS2: OPzS Solar-Cells tubular plate stationary battery.

BS3: OPzS Solar-Blocks flat plate stationary battery

From the data in Table 1, a mathematical model is determined for the different types of battery. The mathematical models determined are given respectively by the following (13-18):

$$
\begin{aligned}
& N_{C(D O D)[\mathrm{BGEL} 1]}=12850 \times e^{-(9.7380 \times D O D)}+3210 \times e^{-(1.429 \times D O D)} \\
& N_{c(D O D)[\mathrm{BGEL} 2]}=13820 \times e^{-(7.2460 \times D O D)}+3210 \times e^{-(1.139 \times D O D)}
\end{aligned}
$$




$$
\begin{aligned}
& N_{C(D O D)[\mathrm{BGEL} 3]}=14690 \times e^{-(5.8276 \times D O D)}+4391 \times e^{-(1.021 \times D O D)} \\
& N_{C(D O D)[\mathrm{BS} 1]}=11250 \times e^{-(9.3460 \times D O D)}+2863 \times e^{-(1.170 \times D O D)} \\
& N_{C(D O D)[\mathrm{BS} 2]}=24090 \times e^{-(9.3460 \times D O D)}+6085 \times e^{-(1.319 \times D O D)} \\
& N_{C(D O D)[\mathrm{BS} 3]}=14850 \times e^{-(7.9800 \times D O D)}+3766 \times e^{-(1.158 \times D O D)}
\end{aligned}
$$

Where $N_{c}$ is the maximum number of battery cycles.

Figure 4 groups the characteristics of the maximum number of cycles according to the DOD for the 6 lead-acid batteries studied. The class (OPEN or GEL) does not have much influence on the lifetime, it is more the technology of the shape of the plates that is important. The tubular shape (BGEL3 and BS2) has a longer service life than the flat shape, but with more limited charging and discharging currents than in flat technology. For the rest of the article, it is the type GEL-VRLA SOLAR battery (BGEL1) which is taken as an example.

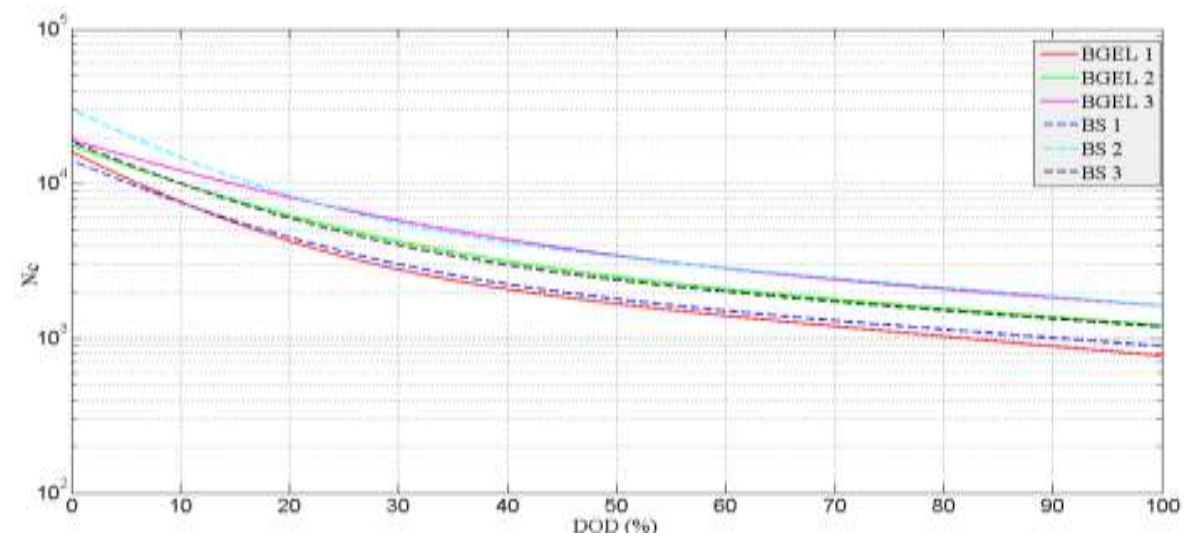

Figure 4. Cycle number variation according to DOD

\section{b) Extraction of operating cycles by rainflow algorithm}

The first use of the Rainflow algorithm [17] was applied for the study of material fatigue. The principle of this algorithm is based on the extraction of the cycles carried out by the monitored quantity. In the field of mechanics, the fatigue of materials is determined generally from the cycles of effort. For the lifetime of a battery, the use of the same algorithm on the state of charge of the battery gives a similar result [18-28]. Thus, the Rainflow algorithm has been applied in the example of Figure 2. It allows to extract the number of cycles of the signal with its corresponding depth of discharge. The result is in the form of Figure 5 (DOD/Cycle) by giving the depth of discharge of each cycle extracted. For the example chosen, 651 cycles were extracted. Note that for each cycle, the depth of discharge is different. It is these operating cycles that will be used to study the aging of the battery.

\section{c) Calculation of the aging of the battery}

Aging is defined from the battery life cycle characteristic $N_{c(D O D)}$ of Figure 3. For example, a DOD $=100 \%$ corresponds to 770 cycles for the life of the battery. That is, aging for a cycle with a DOD $=100 \%$ corresponds to $1 / 770$ of life. Thus, an aging rate per cycle is calculated as a function of the DOD $\left(T_{v / c(D O D)}\right)$ being the inverse of $\left(N_{C(D O D)}\right)$. The relation is written in the following form (19):

$$
T_{v / c(D O D)}=\frac{1}{N_{C(D O D)}}
$$

Figure 6 shows each aging rate per cycle of the battery. To calculate the aging over a one-year operating period, it is necessary to sum the aging of each cycle determined by the Rainflow algorithm of Figure 5 taking into account the depth of discharge. Thus, the formula of the aging rate over a given period of time is in the following form (20): 


$$
T_{v}=\sum_{N_{c}}^{651}\left(T_{v / c(D O D)}\right)
$$

To summarize the procedure followed to calculate the aging rate for a given duration, Figure 7 illustrates all the steps that have been developed.

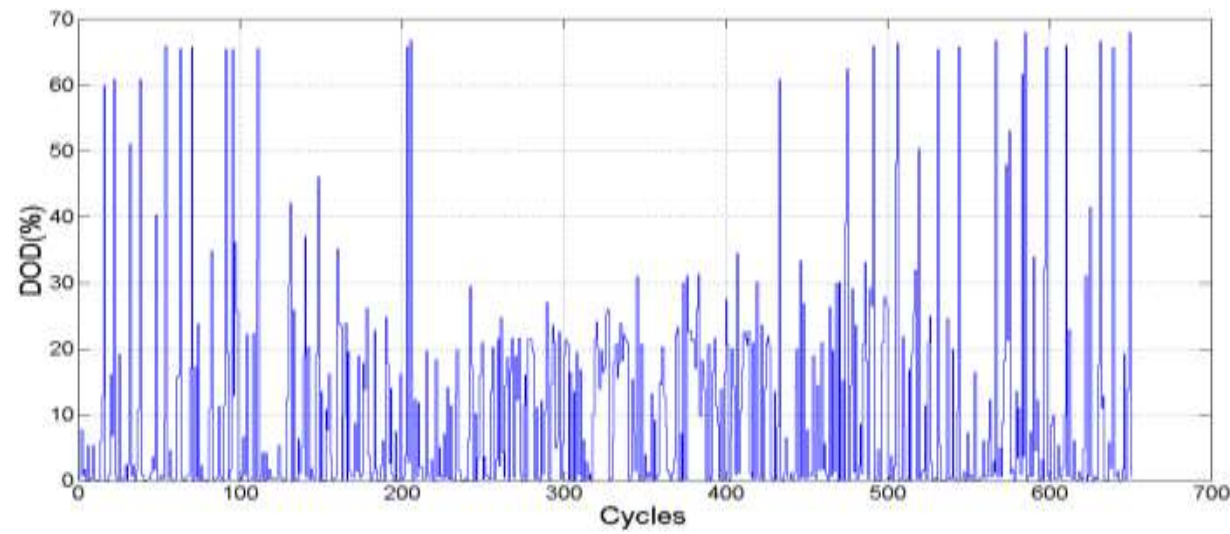

Figure 5. Depth of discharge according to each cycle performed by the battery

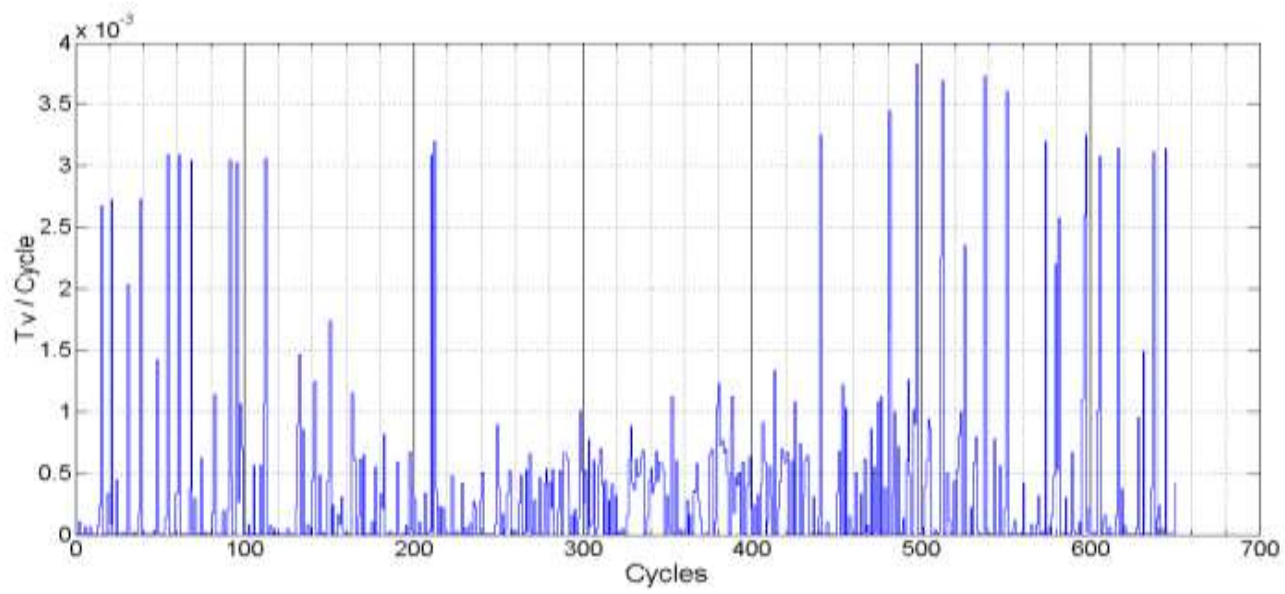

Figure 6. Evolution of aging rate according to cycles

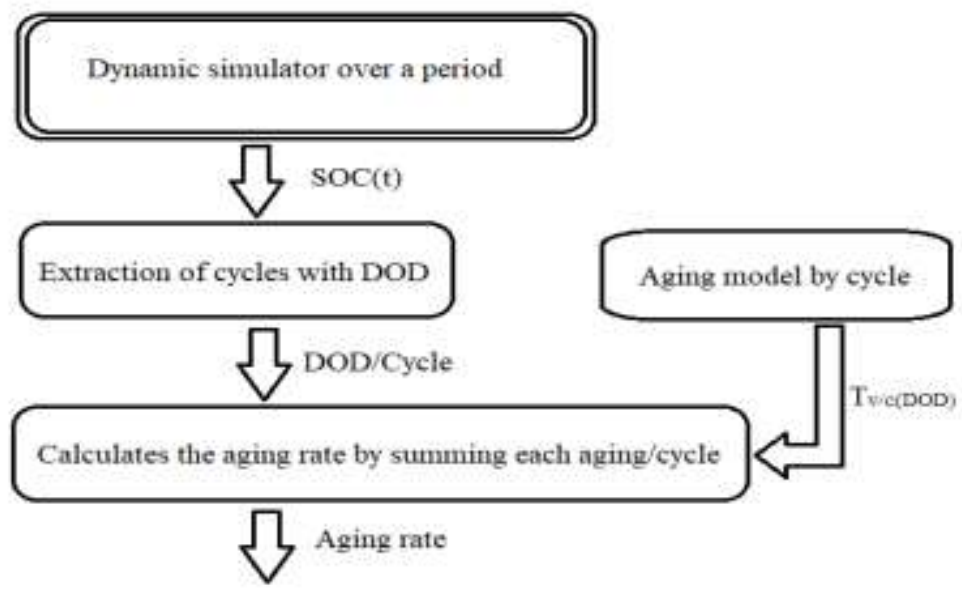

Figure 7. Aging model of the battery 


\section{RESULTS AND DISCUSSION}

Using the example of Figure 2 gave a total aging rate $\mathrm{T}_{\mathrm{V} / \mathrm{years}}=10.30 \%$. Which means that in our application, the lead-acid battery pack, will have a lifetime of 9.7 years. To exploit this method, it is possible to test the influence of the choice of the maximum depth of discharge in the battery management of the multisource system.

Several simulation tests are presented in Table 3. For a constant battery capacity equal to 220Ah, we determined the aging rate corresponding to each maximum discharge depth. In the range of DOD variations $[20 \%-70 \%]$, there is only a small influence about $10 \%$ on the service life, due to the small increase in the number of cycles obtained by the algorithm Rainflow.In addition, the dynamic simulator gives the starting number of the diesel group. On the other hand, for this datum, the limit of the maximum depth of the battery has a strong influence on the aging of the diesel group. Thus, this method will make it possible to optimize the aging of each element of the multi-source system.

Table 3. Aging rate for several depths of discharge with a capacity $\mathrm{C}=220 \mathrm{Ah}$

\begin{tabular}{cccccc}
\hline DOD $(\%)$ & 20 & 30 & 45 & 60 & 70 \\
\hline $\mathrm{T}_{\mathrm{V} / \text { years }}(\%)$ & 9.26 & 9.51 & 9.82 & 9.95 & 10.32 \\
Lifetime (year) & 10.80 & 10.50 & 10.17 & 10 & 9.7 \\
Nb of Start/Stop (GD) & 195 & 79 & 40 & 26 & 21 \\
Number of cycles & 786 & 691 & 668 & 656 & 652 \\
\hline
\end{tabular}

\section{CONCLUSION}

This article presents an approach for estimating the aging of an integrated storage bank within a multi-source hybrid system. It is based on the use of a dynamic simulator taking into account the parameters of the internal elements (wind, PV, battery, management algorithm) and also the external demands (meteorological data and the load) and the data from the battery manufacturer. This estimation method of battery aging is essential for optimizing the design of internal elements of the multi-source systems.

\section{REFERENCES}

[1] T. M. Layadi, M. Mostefai, G. Champenois, and D. Abbes, "Dimensioning a hybrid electrification system (PV/WT/DG+ battery) using a dynamic simulation," in 2013 International Conference on Electrical Engineering and Software Applications, pp. 1-6, 2013.

[2] R. Dufo-López and J. L. Bernal-Agustín, "Design and control strategies of PV-Diesel systems using genetic algorithms," Sol. Energy, vol. 79, no. 1, pp. 33-46, Jul. 2005.

[3] E. Koutroulis, D. Kolokotsa, A. Potirakis, and K. Kalaitzakis, "Methodology for optimal sizing of stand-alone photovoltaic/wind-generator systems using genetic algorithms," Sol. Energy, vol. 80, no. 9, pp. 1072-1088, Sep. 2006.

[4] D. B. Nelson, M. H. Nehrir, and C. Wang, "Unit sizing and cost analysis of stand-alone hybrid wind/PV/fuel cell power generation systems," Renew. Energy, vol. 31, no. 10, pp. 1641-1656, 2006.

[5] R. Belfkira, L. Zhang, and G. Barakat, "Optimal sizing study of hybrid wind/PV/diesel power generation unit," Sol. Energy, vol. 85, no. 1, pp. 100-110, Jan. 2011.

[6] D. Abbes, A. Martinez, and G. Champenois, "Eco-design optimisation of an autonomous hybrid wind-photovoltaic system with battery storage," IET Renew. Power Gener., vol. 6, no. 5, pp. 358-371, Sep. 2012.

[7] D. Abbes, A. Martinez, G. Champenois, and J.-P. Gaubert, "Étude d'un système hybride éolien photovoltaïque avec stockage: Dimensionnement et analyse du cycle de vie," Eur. J. Electr. Eng. EJEE, vol. 155, pp. 479-497, 2012.

[8] D. Abbes, A. Martinez, and G. Champenois, "Life cycle cost, embodied energy and loss of power supply probability for the optimal design of hybrid power systems," Math. Comput. Simul., vol. 98, pp. 46-62, Apr. 2014.

[9] E. M. Laadissi, E. F. Anas, and M. Zazi, "Nonlinear Black Box Modeling of a Lead Acid Battery using Hammerstein-Wiener Model.," J. Theor. Appl. Inf. Technol., vol. 89, no. 2, 2016.

[10] B. Bogno et al., "Improvement of safety, longevity and performance of lead acid battery in off-grid PV systems," Int. J. Hydrog. Energy, vol. 42, no. 5, pp. 3466-3478, 2017.

[11] M. S. Rahmanifar, "Enhancing the cycle life of Lead-Acid batteries by modifying negative grid surface," Electrochimica Acta, vol. 235, pp. 10-18, 2017.

[12] Lambert DW, Greenwood PH, Reed MC. "Advances in gelled-electrolyte technology for valve-regulated lead-acid batteries", Journal of power sources, vol. 107, no. 2, pp. 173-179, 2002.

[13] A. H. Anbuky and P. E. Pascoe, "VRLA battery state-of-charge estimation in telecommunication power systems," IEEE Trans. Ind. Electron., vol. 47, no. 3, pp. 565-573, Jun. 2000.

[14] N. Khera, S. A. Khan, and O. Rahman, "Valve regulated lead acid battery diagnostic system based on infrared thermal imaging and fuzzy algorithm," Int. J. Syst. Assur. Eng. Manag., Feb. 2020. 
[15] Catherino HA. "Complexity in battery systems: Thermal runaway in VRLA batteries". Journal of PowerSources, vol. 158, no. 2, pp. 977-986, 2006.

[16] A. Zainuri, U. Wibawa, M. Rusli, R. N. Hasanah, and R. A. Harahap, "VRLA battery state of health estimation based on charging time," TELKOMNIKA (Telecommunication, Computing, Electronics and Control), vol. 17, no. 3, 2019.

[17] S. D. Downing and D. F. Socie, "Simple rainflow counting algorithms," Int. J. Fatigue, vol. 4, no. 1, pp. 31-40, 1982.

[18] A. Gheiratmand, R. Effatnejad, and M. Hedayati, "Technical and economic evaluation of hybrid wind/PV/battery systems for off-grid areas using HOMER software," Int. J. Power Electron. Drive Syst., vol. 7, no. 1, p. 134, 2016.

[19] W. Tiezhou, C. Quan, L. Lunan, X. Qing, and W. Xieyang, "Research on the fast charging of VRLA, "TELKOMNIKA Indones. J. Electr. Eng., vol. 10, no. 7, pp. 1660-1666, 2012.

[20] Chan CC, Lo EW, Weixiang S. "The available capacity computation model based on artificial neuralnetwork for lead-acid batteries in electric vehicles". J. Power Sources, vol 87, pp. 201-204, 2000.

[21] Bhangu BS, Bentley P, Stone DA, Bingham CM. "Nonlinear observers for predicting state-of-chargeand state-ofhealth of lead-acid batteries for hybrid-electric vehicles". IEEE Trans. Veh. Tech,vol. 54, pp. 783-794, 2005.

[22] Kim IS. "A technique for estimating the state of health of lithium batteries through a dual-sliding-modeobserver". IEEE Trans. Power Electronics, vol. 25, pp. 1013-1022, 2010.

[23] Haifeng D, Xuezhe W, Zechang S. "A new SOH prediction concept for the power lithium-ion batteryused on HEVs". Vehicle Power and Propulsion Conference. Dearborn, pp. 1649-1653, 2009.

[24] Shahriari M, Farrokhi M. "State of health estimation of VRLA batteries using fuzzy logic". 18th IranianConference on Electrical Engineering. Isfahan, pp. 629-634, 2010.

[25] Lin HT, Liang TJ, Chen SM. "Estimation of Battery State of Health Using Probabilistic Neural Network". IEEE Transactions on Industrial Informatics, vol. 9, no. 2, pp. 679-685, 2013.

[26] Kim T, Qiao W, Qu L. "Online SOC and SOH estimation for multicell lithium-ion batteries based on anadaptive hybrid battery model and sliding-mode observer". IEEE Energy Conversion Congress andExposition. Denver. pp. 292-298, 2013.

[27] Qiuting W. "State of Health Estimation for Lithium-ion Battery Based on D-UKF". International Journalof Hybrid Information Technology, vol. 8, no. 7, pp. 55-70, 2015.

[28] Moura JS, et.al. "Adaptive Partial Differential Equation Observer for Battery State of charge/State ofHealth Estimation via an Electrochemical Model". Journal of Dynamic System, Measurement and Control, Transaction ASME, vol. 136, pp. 1-11, 2014. 